\section{PROPOSED ZOOLOGICAL STATION AT GRANTON, NEAR EDINBURGH}

$A^{T}$ the half-yearly meeting of the Scottish Meteorological Society held at Edinburgh on Thursday last week, Mr. John Murray, convener of the Society's Fisheries Committee, submitted the following Report :-

"The Fisheries Committee of the Council appointed in February last have had under their careful consideration the matters remitted to them by the Council, viz. the carrying out of investigations in accordance with the term; of the grant of $1500 l$. made to the Society by the Executive Committee of the International Fisheries Exhibition held in Edinburgh in 1882. The Committee recommends (I) to continue and extend the river observations and the observations made by the District Fishery officers through the Scottish Fishery Board, and to discuss all observations made to the end of the fishing season of 1883 , which are yet undiscussed.

"2. To obtain the assistance of a few naturalists in making observations at several of the chief fishing centres and principal inland lakes. Prof. Herdman has consented to reside at Loch Fyne for a month, and to arrange for observations for a year. Mr. Hoyle is in like manner to go to Peterhead, and Mr. Beddard to Eyemouth. The Rev. Dr. Norman has during the present month been engaged in examining a large number of the Scottish loshs. Instructions have been drawn up for the guidance of these gentlemen, and a sum not exceeding 50l. has been placed at the disposal of each for the expenses immediately connected with the investigations. These observations are of a strictly tentative character, but will certainly lead to additions to knowletge, and are, moreover, necessary as a basis for further investigations.

"3. The Co.nmittee have had under consideration the recommendation of the Executive Committee of the Fisheries Exhibition as to the foundation of a zoological station. A number of the members of Cominittee have examined the capabilitie; of the old Granton Quarry, which has been for many years in direct co.nmunication with the sea, as a suitable position for a zoological station.

"The convener has drafted the following scheme, which in the opinion of the Committee would, if carried out, afford excellent facilities for biological researches and meteorological observations bearing upon these inquiries:- It is proposed to inclose the Granton quarry, which has an area at high water of about ten acres, and depths varying to sixty feet, so as to rezulate the inflow and outflow of the tide in such a manner that while admitting abundance of sea water at each tide, fish and other animals will be prevented from escaping out of the inclosure. This will be done by means of stakes and wire with other kinds of netting. The quarry will then be stocked with all kinds of fish and marine invertebrates. When it is desired to separate fish or other animals for special study this will be done by floating or fixed wire and wood cages.

"A barge, about 64 feet by 27 feet, of great stability, will be moored in the inclosure; upon this will be built a house with laboratories, workrooms, and a library; it will also be furnished with a small windmill to pump up sea water into a tank on the roof. The water in this tank will be conveyed by pipes to the various tiled tables, glass jars, and aquaria of the establishment. A small cottage will be built on the shore for the accommodation of the keeper and engineer, with one or two spare rooms. A steam pinnace for dredging and making objervations in the Firth of Forth and the North Sea will be attached to the station.

"A naturalist will be appointe 1 whose duty will be to make continuous observations and experiments, assisted by the engineer and keeper. There will be ample accommodation for four other naturalists to work at the station and carry on investigations; and, so far as the accommodation will permit, British and foreign naturalists will be invited to make use of the station free of charge.

"Towards the carrying out of this scheme the Duke of Buccleuch has liberally granted a lease of the quarry at a nominal rent, with permission to erect a cottage on the shore; and Mr. Howkins, his Grace's local commissioner, has promised all the assistance in his power to further the undertaking. A gentleman who takes a warm interest in the progress of research in Scotland has offered roool. to construct the barge and fit it up with laboratories and workrooms. Mr. John Henderson (of Messrs. D. and W. Henderson, shipbuilders, Glasgow) has undertaken to provide the plans and specifications of the barge and laboratories gratuitously; Mr. J. Y. Buchanan has promised to fit up one of the rooms on the barge as a chemical laboratory suited to the requirements of the station; Mr. 'Thomas Stevenson, the Society's Honorary Secretary, has agreed to give his professional services in inclosing the quarry gratuitously; and Mr. John Anderson, of Denham Green, has undertaken to provide the station with a salmon and trout hatchery. The convener will furnish the laboratories with apparatus, and place his large zoological library at the service of workers. A number of gentlemen have promised to support the undertaking when once commenced; and the convener believes that within a few months he will be able to announce that the station has been presented with a steam pinnace and with funds for the erection of a cottage on the shore-the only desiderata to complete the scheme.

"In these circumstances the Committee, believing that this scheme deserves their hearty support, recommend, for the year ending November 1, 1834, a grant from the Fishery Fund not exceeling $300 \mathrm{l}$, and $250 l$. for each of the two subsequent years, towards the expenses of the station, on the conditions that the biological and meteorological observations and the investigations above referred to, relative to the Scottish fisheries, be carried on, and that a report on the work done be annually furnished to the Council of the Society."

The above grants were agreed to, and it was announced that the works at Granton would be com nenced at once. It is expected that by the beginning of November the proper work of the station will be begun. Already, we understand, several distinguished naturalists have signified their intention to avail themselves of the altogether unique facilities which will be afforded by this zoological station for the successful prosecution of biological research. It is gratifying to observe the heartiness with which the funds required for carrying out this admirable scheme are being provided, and it cannot be doubted that the $800 \%$. still required for the steam pinnace, the $500 l$. for the cottage, and the $200 \mathrm{l}$. for inclosing the quarry will also be soon provided by some of our more generous patrons of science.

\section{ELEVATION AND SUBSIDENCE; OR, THE PERMANENCE OF OCEANS AND CON- TINENTS}

$\mathrm{I}^{\mathrm{T}}$ has been observed, and with increasing frequency within the last few years, that wherever considerable weight is added on any part of the earth's surface, a corresponding subsidence of its crust almost invariably follows. It is generally admitted that nearly the whole of the sedimentary rocks, enormous as their known thickness is, were deposited in shallow water, and therefore in slowly subsiding areas. The Palæozoic rocks consist mainly of sandy and muddy sediment, with ozcasional intercalated zones of limestone. They everywhere bear witness to comparatively shallow water and the proximity of land. Their frequent alternations of sandstone, shale, conglomerate, and other detrital materials, their abundant 